УДК 378.147

DOI:

Юлія Мельничук, кандидат педагогічних наук, стариий викладач кафедри комп'ютерних наук

Луцького національного технічного університету

Олена Фурман, кандидат педагогічних наук, доцент кафедри теорії і методики трудового навчання та технологій Кременеиької обласної гуманітарно-педагогічної академії імені Тараса Шевченка

Надія Бабій, кандидат технічних наук, доиент кафедри теорії і методики трудового навчання та технологій Кременеиької обласної гуманітарно-педагогічної академії імені Тараса Шевченка

Іванна Саланда, кандидат технічних наук, доцент кафедри теорії і методики трудового навчання та технологій Кременеиької обласної гуманітарно-педагогічної академії імені Тараса Шевченка Ігор Галаган, кандидат педагогічних наук, старший викладач кафедри теорії і методики трудового навчання та технологій Кременеиької обласної гуманітарно-педагогічної академії імені Тараса Шевченка

\title{
СТВОРЕННЯ ТА ВИКОРИСТАННЯ ВІРТУАЛЬНОГО КАБІНЕТУ ІНФОРМАТИКИ В ОСВІТНЬОМУ СЕРЕДОВИЩІ НУШ
}

Стаття присвячена розгляду проблеми створення та використання віртуального кабінету інформатики в освітньому середовищі Нової української школи. Здійснено огляд предметної області дослідження, проаналізовано кониепиії, функиії та особливості віртуальних кабінетів. Представлена структурно-функиіональна схема роботи віртуального кабінету інформатики; описано платформу для розробки, послідовність проєктування та функціонування віртуального кабінету. Віртуальний кабінет інформатики впроваджено в освітніє середовище нової украӥнської школи; окреслено перспективи наступних наукових досліджень у руслі обраної тематики.

Ключові слова: віртуальне освітнє середовище; віртуальний кабінет; інформатика; початкова школа; система управління контентом.

Puc. 3. Лim. 8.

Juliya Melnychuk, Ph.D.(Pedagogy), Senior Lecturer of the Computer Science Department Lutsk National Technical University

Olena Furman, Ph.D.(Pedagogy), Associate Professor of the Theory and Methods of Labor Training and Technology Department Kremenets Taras Shevchenko Regional Humanitarian and Pedagogical Academy Nadiya Babiy, Ph.D.(Technical Sciences), Associate Professor of the Theory and Methods of Labor Training and Technology Department Kremenets Taras Shevchenko Regional Humanitarian and Pedagogical Academy

Ivanna Salanda, Ph.D.(Technical Sciences), Associate Professor of the

Theory and Methods of Labor Training and Technology Department Kremenets Taras Shevchenko Regional Humanitarian and Pedagogical Academy

Ihor Halahan, Ph.D.(Pedagogy), Senior Lecturer of the

Theory and Methods of Labor Training and Technology Department

Kremenets Taras Shevchenko Regional Humanitarian and Pedagogical Academy

\section{CREATION AND USE OF THE VIRTUAL CABINET OF INFORMATICS IN THE EDUCATIONAL ENVIRONMENT OF NUS}

The article is devoted to the problem of creating and using a virtual computer science classroom in the educational environment of the new Ukrainian school. The purpose of this article is the process of designing and implementing a virtual computer science classroom for elementary school students based on CMS WordPress. The key research concepts, approaches and principles of designing virtual classrooms are identified, analyzed and generalized. The subject area of research is reviewed, the concepts, functions and features of virtual classrooms are analyzed. The structural and functional scheme of work of a virtual office of computer science is presented; describes the platform for the development, design sequence and operation of the virtual cabinet. The content and structure of the virtual computer science classroom for primary school students have been developed and theoretically 


\section{СТВОРЕННЯ ТА ВИКОРИСТАННЯ ВІРТУАЛЬНОГО КАБІНЕТУ ІНФОРМАТИКИ В ОСВІТНЬОМУ СЕРЕДОВИЩІ НУШ}

substantiated, taking into account the needs of the subjects of this educational unit. The technique of application of a virtual office of computer science in educational process is developed. The virtual computer science classroom has been introduced into the educational environment of the new Ukrainian school; the prospects of the following scientific researches in the line of the chosen subject are outlined. The practical significance of the study is revealed in highlighting the benefits of using a virtual classroom as a means of conducting classes, demonstrating educational presentations and interactive textbooks to explain new material, consolidating knowledge of computer science in primary school. In the course of the research the system of teaching informatics in primary school was improved, which is expressed in the creation of the designed software of pedagogical direction, creation of educational material for conducting lessons of informatics in primary school. The development can be used by parents of schoolchildren, computer science teachers, trainee students during pedagogical internships.

Keywords: virtual educational environment; virtual office; computer science; primary school; content management system.

3 агальна постановка проблеми. Актуальність дослідження зумовлена зміною орієнтирів та вимог до викладання інформатики в умовах нової української школи (НУШ) як до базової ланки сучасної освіти, що готує учня до життя в інформаційному соціумі. Система шкільної освіти характеризується розширенням спектру педагогічних технологій, що застосовуються, значним розповсюдженням інновацій та експериментальної діяльності. Інформаційний простір, організований з допомогою комп'ютерної техніки та мережі Інтернет, 3 можливістю участі у форумах, чатах, онлайн-конференціях, семінарах, створення різноманітного контенту, став звичним середовищем для спілкування, відпочинку, роботи та навчання.

Поняття віртуальної освіти можна трактувати як процес та результат взаємодії суб'єктів і об'єктів, що супроводжується створенням ними віртуального освітнього простору, специфіку якого виділяють саме дані суб'єкти та об'єкти Віртуальний простір не може існувати без комунікаційного процесу між учителем та учнем. Таким чином, віртуальний освітній простір актуалізується лише в реальних умовах педагогічної взаємодії, що породжує різноманітну діяльність, та існує доти, доки є активною породжувальна діяльність.

Віртуальне освітнє середовище становить інтеграцію інформаційних, комунікаційних та віртуальних технологій, сприяє інтерактивному управлінню процесом засвоєння знань, формуванню ключових компетентностей. Віртуальне освітнє середовище доцільно використовувати не тільки з навчальною метою, а й для розв'язання мотиваційної, інформаційної, виховної, профорієнтаційної, комунікаційної, психокорекційної та розвивальної задач, що забезпечують створення умов для самовдосконалення особистості учня.

Віртуальний кабінет інформатики - форма мережевої взаємодії, інтерактивного спілкування різних суб'єктів освітнього процесу, віртуальний методичний простір, що дає змогу педагогам ділитися досвідом та корисними посиланнями, розміщувати медіаресурси і т.д.

Серед головних переваг варто зауважити: мобільність, доступ до інформації у будь-який час доби; оперативну методичну допомогу молодим педагогам; створення електронної бази освітніх технологій та діагностичних інструментів; спільний пошук розв'язання проблем; робота в дослідницьких та творчих мікрогрупах i макрогрупі.

У ракурсі останніх змін у системі початкової ланки шкільної освіти, віртуальний кабінет розглядається як одна із найважливіших ланок інформаційно-освітнього середовища, що сприяє попередженню та мінімізації ризиків, пов'язаних із цією модернізацією. Означене середовище динамічно відображає запити учителів, організується у режимі професійного спілкування, створює реальні можливості побудови відкритої системи неперервної освіти. Різнорівнева та динамічна структура віртуального кабінету перебуває у постійному процесі розвитку та наповнення, дає змогу кожному учасникові знайти чи змоделювати індивідуальну освітню нішу, у якій він найбільш повно зможе реалізувати свої професійні запити та можливості, побудувати траєкторію самоосвіти.

Аналіз основних досліджень і публікацій. Для результативного досягнення мети дослідження на першому його етапі було ретельно оглянуто науковий доробок науковців в обраній галузі. На наш погляд, уваги заслуговують дослідження щодо навчання інформатики у початковій школі Н. Стасів [8], В. Глазової [3], Я. Донченко [5], Н. Кайдан [6], В. Антонюк [1], та ін.

Метою статті $є$ процес конструювання та реалізації віртуального кабінету інформатики для учнів початкових класів на основі CMS WordPress.

Виклад основного матеріалу. Віртуальний кабінет дає змогу узагальнювати методичну роботу педагогічних працівників, зберігати та реалізувати педагогічний досвід, що міститься в 


\section{СТВОРЕННЯ ТА ВИКОРИСТАННЯ ВІРТУАЛЬНОГО КАБІНЕТУ ІНФОРМАТИКИ В ОСВІТНЬОМУ СЕРЕДОВИЩІ НУШ}

інформаційному середовищі, мінімізувати час на пошук необхідної інформації, оскільки передбачає доступ до неї без часових та просторових рамок.

До базових принципів роботи віртуального кабінету належать [2]:

1. Гнучкість - можливість вибору оптимального темпу та індивідуального режиму роботи. Педагогічні працівники самостійно планують зручний час та регламент для ознайомлення 3 матеріалами.

2. Доступність - доступ до актуальної інформації у будь-який час, із будь-якої точки, із будь-якого it-пристрою (персональний комп’ютер, планшет, смартфон і т.д.)

3. Відкритість - забезпечення доступу учасникам до нормативних документів, програмно-методичних матеріалів, розміщених на веб-ресурсах, можливість перегляду усіх відкритих Інтернет-ресурсів, які можуть містити потрібні дані.

4. Масовість - можливість доступу до ресурсу усіх необхідних учасників, можливість неодноразового звернення до розміщеної інформації.

5. Системність - блочно-модульна система розміщення матеріалів. Блок - певна частина цілісної діяльності, що є сукупністю функціонально об'єднаних модулів. Модуль - логічно завершена частина розділу.

Спрямованість діяльності віртуального кабінету:

- інформаційно-діагностична (формування банку педагогічної інформації; інформування учасників кабінету про нові напрямки у розвитку освіти; залучення відвідувачів віртуального кабінету до інноваційної діяльності);

- організаційно-методична (методичний супровід та надання практичної допомоги молодим фахівцям та ін.);

- консультативно-методична.

Таким чином, віртуальний кабінет інформатики структурує інформаційні матеріали за блоковомодульним принципом із врахуванням цілей та завдань освіти, напряму діяльності НУШ; формує фонд нормативно-методичної документації відповідно до вимог освітніх та професійних стандартів; створення організаційно-педагогічних умов для реалізації запитів педагогів, учнів та їх батьків щодо вивчення навчальних дисциплін; інформування учасників про основні напрями розвитку професійної освіти; надання методичної допомоги та підвищення професійної компетентності педагогів; узагальнення та пропаганда кращого педагогічного досвіду.

Концепція побудови віртуального кабінету інформатики співзвучна із положеннями освітнього стандарту щодо викладання цієї дисципліни, зокрема [4]:

- засвоєння знань, що складають основу наукових уявлень про інформацію, інформаційні процеси, системи, технології та моделі;

- оволодіння уміннями працювати із різноманітними видами інформації з допомогою комп'ютера та інших засобів інформаційнокомунікаційних технологій, організація власної інформаційної діяльності та планування їїрезультатів;

- розвитокпізнавальних інтересів, інтелектуальних та творчих здібностей засобами IКТ;

- виховання відповідального ставлення до інформації із врахуванням правових та етичних аспектів їі розповсюдження; вибіркового ставлення до отриманої інформації;

- вироблення навиків застосування засобів IКТ у повсякденному житті, при виконанні індивідуальних та колективних проєктів, у навчальній діяльності, при подальшому освоєнні професій, затребуваних на ринку праці.

Новизна дослідження полягає у розгляді віртуального кабінету як засобу навчання інформатики у початковій школі, методичного супроводу для вчителя, підвищення його педагогічної майстерності; в обгрунтуванні можливості його використання у навчальному процесі, у розробці нових методик навчання інформатики у початковій школі.

Функції розроблюваного ресурсу такі:

Інформативність - ресурс, передовсім має інформативний характер. Суб'єкти у будь-який час можуть зайти у віртуальний кабінет та дізнатись необхідну їм інформацію.

Збір інформаџї за заданою темою - уся інформація чітко структурована. Це реалізовано, аби адміністратору було зручно працювати 3 матеріалами, а користувачі могли легко знайти необхідну інформацію.

Обмін даними - реалізація обміну повідомленнями через заповнення форми зворотного зв'язку.

Структурна схема - це сукупність елементарних ланок об'єкта та зав'язків між ними, один із видів графічної моделі.

Функціональна схема - це документ, що роз'яснює процеси, які відбуваються в окремих функціональних ланцюгах об'єкта чи об’єкті загалом. Функціональна схема є експлікацією (пояснювальним матеріалом) окремих видів процесів, що протікають у цілісних функціональних блоках і модулях об'єкта.

Отже, структурно-функційна схема віртуального кабінету інформатики для учнів початкових класів має вигляд (рис.1): 


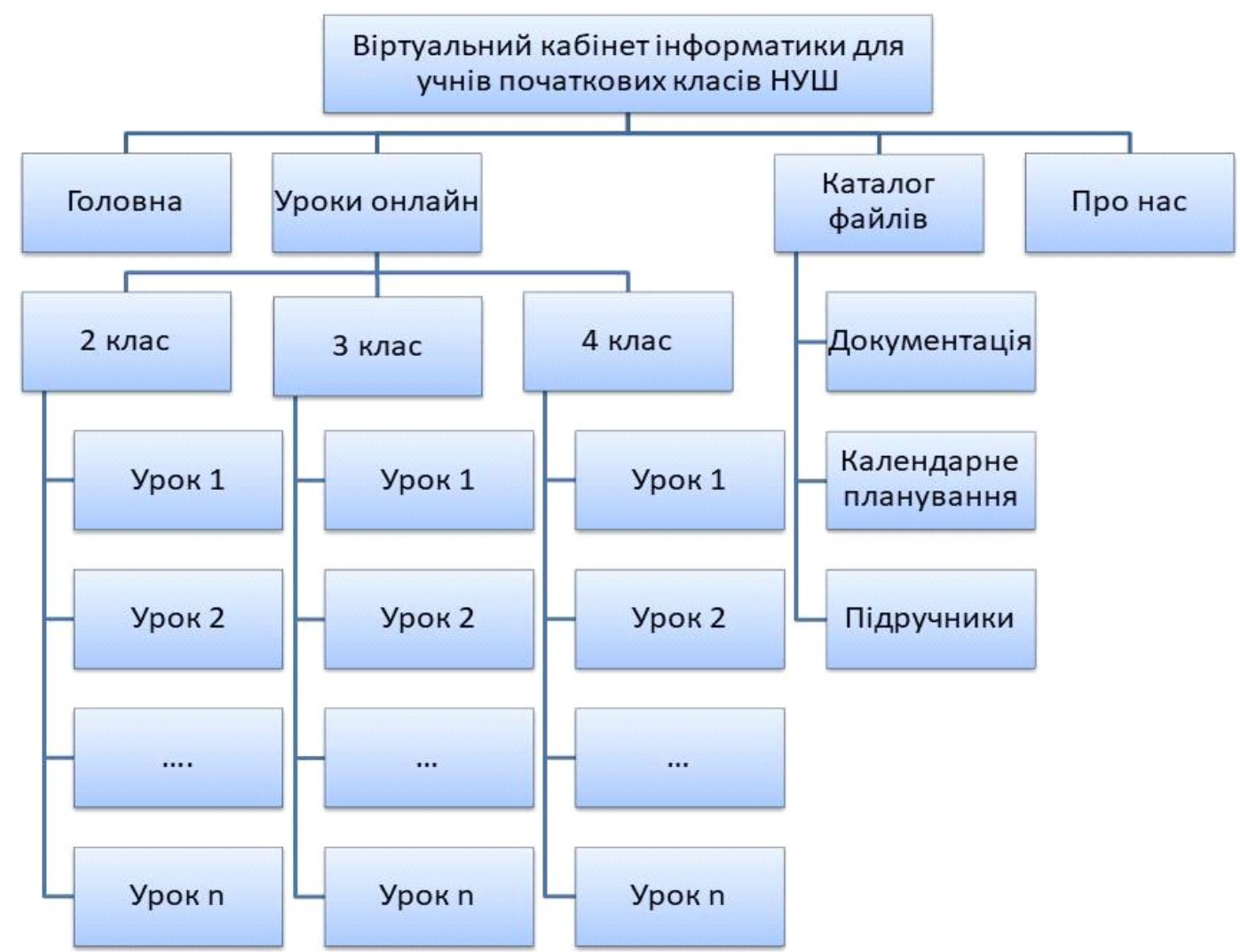

Рис. 1. Структурно-функціональна схема віртуального кабінету інформатики для початкових класів НУШ

Схема розроблюваного віртуального кабінету інформатики інтуїтивно зрозуміла та відображає головні блоки системи.

Блок “Головна" відображає головну сторінку веб-ресурсу віртуального кабінету інформатики, містить карту сайту та форму для оформлення підписки на оновлення в кабінеті.

Блок "Уроки онлайн” має у підорядкуванні три модулі: “2 клас", “3 клас" та "4 клас”, кожен 3 яких містить розробки проведення уроків у відповідному класі.

У модулях блоку “Каталог файлів" розміщена нормативно-правова база навчання інформатиці, календарне планування для вчителя та сукупність підручників 3 інформатики для початкової школи.

Блок “Про нас" містить інформацію про місцезнаходження та контакти відповідного закладу освіти, який обслуговує цей віртуальний кабінет; форму для зворотного зв'язку.

Зовнішній вигляд розробленої системи проілюстровано на рис. 2. Для доступу можна використовувати будь-який браузер. Віртуальний кабінет коректно працює і на мобільних пристроях.

Стартова сторінка складається із таких елементів: шапка сайту, що містить його назву та меню; карта сайту; форма для підписки на новини віртуального кабінету; кнопки соціальних мереж, у яких можна поділитись сторінкою.

Меню віртуального кабінету складається із чотирьох компонентів: “Головна", "Уроки онлайн”, “Каталог файлів" та "Про нас", при натисненні на які відкривається відповідна сторінка. Пункти “Уроки онлайн” та “Каталог файлів" містять підпорядковані сторінки.

Сторінка "Уроки онлайн” дозволяє вибрати клас, для якого необхідно переглянути матеріали (рис.3).

При виборі необхідного класу, відкривається сторінка із тематиками уроків, що відповідають календарному плануванню.

Уроки супроводжуються розробленими конспектами та мультимедійними матеріалами для проведення. Для кожного заняття розроблена методика проведення та вмонтована презентація.

Вкладка “Каталог файлів" має у підпорядкуванні сторінки “Документація”, “Календарне планування” та "Підручники”.

Сторінка “Про нас" містить контактну інформацію розробників та форму для зворотного зв'язку.

Віртуальний кабінет інформатики для 


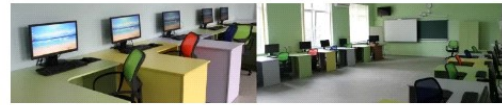

Віртуальний кабінет інформатики для учнів початкових класів ЛНВК «Гімназія №14 ім. Василя Сухомлинського»
Головна Уроки онлайн -

Каталог файлів - Про нас

\section{Вітаємо на нашому сайті!}

Шановний відвідувачу! Ви потрапили до віртуального кабінету інформатики для учнів початкових класів. Тут ви зможете знайти

всю необхідну інформацію для вивчення ціеї захоплюючої дисципліни. На сайті розміщені матеріали для вчителів, батьків та учнів.
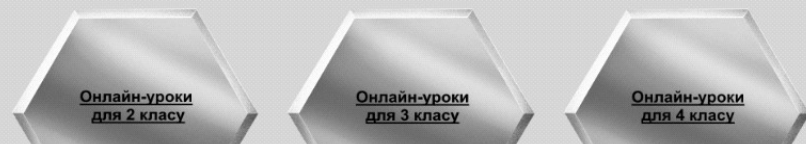

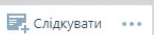

Рис. 2. Інтерфейс віртуального кабінету інформатики для початкових класів НУШ

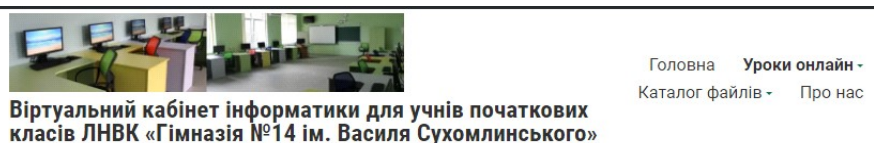

\section{Уроки онлайн}

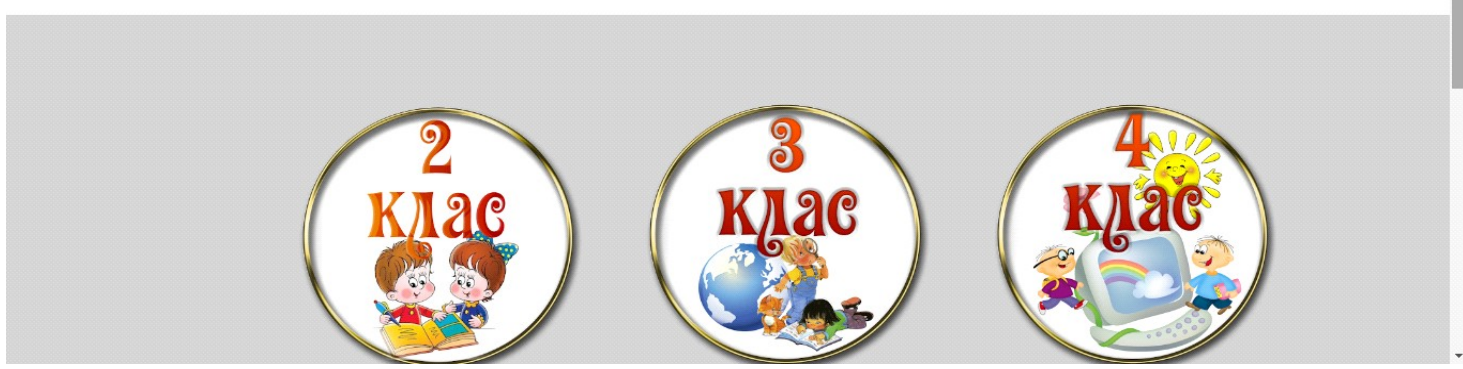

Рис. 3. Інтерфейс сторінки "Уроки онлайн"

початкових класів НУШ створено $з$ допомогою системи управління контентом WordPress.

Платформа характеризується можливістю автоматичного крос-посту у соціальні мережі, входом для коментування з допомогою соціальних мереж, вподобайками для постів, сповіщеннями по електронній пошті, роботи 3 формами зворотного зв'язку, кнопками “Поділитись” для різних соціальних мереж та багато іншого.

Висновки. Результатом проведеного дослідження стала практична реалізація віртуального кабінету інформатики для учнів початкових класів НУШ. Практика показує, що реалізація сучасних форм використання комп'ютерних технологій у Новій українській школі повинна бути частиною цілісної системи та комплексу заходів 3 розвитку єдиного інформаційно-освітнього простору. Віртуальний освітній простір виступає уже не стільки інструментом, що доповнює систему освіти, скільки імперативом встановлення знань нового порядку.

Практичне значення проведеного дослідження розкривається у висвітленні переваг використання віртуального кабінету як засобу для проведення занять, демонстрації навчальних презентацій та інтерактивних навчальних підручників для пояснення нового матеріалу, закріпленню знань з інформатики у початковій школі. У ході дослідження удосконалена система навчання інформатиці у початковій школі, що виражено у створенні проєктованого ПЗ педагогічного спрямування, створенні навчального матеріалу для проведення уроків інформатики у початковій школі. Розробка може використовуватися батьками школярів, учителями інформатики, студентами-практикантами під час проходження педагогічних практик.

До перспектив наукових досліджень щодо роззвитку віртуального кабінету інформатики віднесемо: 


\section{СТВОРЕННЯ ТА ВИКОРИСТАННЯ ВІРТУАЛЬНОГО КАБІНЕТУ ІНФОРМАТИКИ В ОСВІТНЬОМУ СЕРЕДОВИЩІ НУШ}

\footnotetext{
- розробку та запуск відеоконференцій, “круглих столів”, вебінарів у режимі онлайн;

- проведення віртуальних конкурсів педагогічної майстерності;

- проведення внутрішнього анкетування за напрямами навчально-виховного процесу.
}

\section{ЛІТЕРАТУРА}

1. Антонюк В. Про методи формування художньо-естетичної культури школярів засобами курсу інформатики: теоретичний аспект. Молодь i ринок : щомісяч. наук.-пед. журн. Дрогобич. 2008. № 2 (37). С. 69-74.

2. Воробьев М. Виртуальный методический кабинет как базовый элемент функционирования регионального информационно-ресурсного центра по управлению системой дополнительного образования. Современные проблемы науки и образования. 2015. № 2. С. 490-497.

3. Глазова В. Особливості організації процесу професійної підготовки майбутніх учителів інформатики 3 використанням елементів дистанційного навчання. Молодь $і$ ринок : щุомісяч. наук.-пед. журн. Дрогобич. 2015. №10. C. $107-111$.

4. Державний стандарт загальної середньої освіти в Україні. Інформатика. Освітня галузь “Технологї”. Київ. Освіта України. 2003.

5. Донченко Я. Цілі шкільного курсу інформатики: ретроспективний аналіз. Молодь $i$ ринок : щзомісяч. наук.-пед. журн. Дрогобич, 2016. № 4. С. 157 - 161 .

6. Кайдан Н. Використання систем комп’ютерної математики в процесі математичної підготовки майбутніх учителів математики та фізики. Молодь і ринок ринок : щзомісяч. наук.-пед. журн. Дрогобич. 2015. № 10 (129). С. 36-40.

7. Семенова И. Виртуальный методический кабинет как одна из форм организации самообразования педагогов. Методист. 2011. №9. C. $49-50$.

8. Стасів Н., Війчук Т. Особливості використання навчальних комп'ютерних ігор у початковій школі. Молодь і ринок: щзомісяч. наук.-пед. журн. Дрогобич. 2019. №9. С. 82-85.

\section{REFERENCES}

1. Antonyuk, V. (2008). Pro metody formuvannya khudozhno-estetychnoyi kultury shkolyariv zasobamy kursu informatyky: teoretychnyy aspekt [About methods of formation of art and aesthetic culture of schoolboys by means of a course of computer science: theoretical aspect]. "Youth and market". Monthly scientific-pedagogical journal. Drogobych, Vol. 2 (37), pp. 69-74. [in Ukrainian].
2. Vorobiev, M. (2015). Virtualnyy metodicheskiy kabinet kak bazovyy element funktsionirovaniya regionalnogo informatsionno-resursnogo tsentra po upravleniyu sistemoy dopolnitel'nogo obrazovaniya [Virtual methodological office as a basic element of the functioning of the regional information and resource center for managing the system of additional education]. "Modern problems of science and education”. Vol. 2, pp. 490-497. [in Russian].

3. Hlazova, V. (2015). Osoblyvosti orhanizatsiyi protsesu profesiynoyi pidhotovky maybutnikh uchyteliv informatyky z vykorystannyam elementiv dystantsiynoho navchannya [Features of the organization of the process of professional training of future teachers of computer science with the use of elements of distance learning]. "Youth and market". Monthly scientific-pedagogical journal. Drogobych, Vol. 10, pp. 107-111. [in Ukrainian].

4. Derzhavnyy standart zahalnoyi serednoyi osvity v Ukrayini. Informatyka. Osvitnya haluz "Tekhnolohiyi" (2003). [State standard of general secondary education in Ukraine. Computer Science. Educational branch "Technologies"]. Education of Ukraine. Kyiv [in Ukrainian].

5. Donchenko, J. (2016). Tsili shkilnoho kursu informatyky: retrospektyvnyy analiz. [Objectives of the school course of computer science: retrospective analysis]. "Youth and market". Monthly scientificpedagogical journal. Drogobych, Vol. 4, pp. 156161. [in Ukrainian].

6. Kaydan, N. (2015). Vykorystannya system komp'yuternoyi matematyky $\mathrm{v}$ protsesi matematychnoyi pidhotovky maybutnikh uchyteliv matematyky ta fizyky [The use of computer mathematics systems in the process of mathematical training of future teachers of mathematics and physics.] "Youth and market". Monthly scientificpedagogical journal. Drogobych, Vol. 10 (129), pp. 36-40. [in Ukrainian].

7. Semenova, I. (2011). Virtualnyy metodicheskiy kabinet kak odna iz form organizatsii samoobrazovaniya pedagogov [Virtual methodical office as one of the forms of organizing self-education of teachers]. "Methodist". Vol. 9, pp. 49-50. [in Russian].

8. Stasiv, N. \& Viychuk, T. (2019). Osoblyvosti vykorystannya navchalnykh kompyuternykh ihor u pochatkoviy shkoli [Features of the use of educational computer games in primary school]. "Youth and market”. Monthly scientific-pedagogical journal. Drogobych, Vol. 9, pp. 82-85. [in Ukrainian].

\section{Стаття надійшла до редакції 04.08.2020}

